\title{
Apoxyomenos
- underwater cultural heritage and museum in the service of the local community and tourism
}

\author{
Zrinka Ettinger Starčić, Lošinj Museum \\ Hrvoje Potrebica, University of Zagreb
}

Pred sedemnajstimi leti je bil na morskem dnu nedaleč od Lošinja odkrit bronast kip mladega atleta, imenovan Apoxyomenos. Kip je takoj po odkritju presegel lasten kulturni in umetniški pomen ter postal predmet razprav o dediščini in potrebi po njenem ohranjanju. Ta lepa in do najmanjše podrobnosti izdelana redka podvodna najdba je Hrvaško uvrstila na zemljevid svetovne dediščine; tudi večje države, kjer se nahajajo najpomembnejša muzejska središča na svetu, ne premorejo tako izjemnega predmeta.

Ključne besede: Apoxyomenos, muzej, lokalna skupnost, kulturni turizem

Seventeen years ago, a bronze statue of a young athlete was discovered on the seabed near the island of Lošinj. It was named Apoxyomenos. Immediately after it was discovered, the statue exceeded its cultural and artistic importance and incited deliberations about heritage and the need to preserve it. The beauty and portrayal of details of this unique and very rare artistic underwater find has put Croatia on the world heritage map. There are nations much bigger than Croatia, and world famous museum centres, that cannot boast an artefact as sensational as this one.

Keywords: Apoxyomenos, museum, local community, cultural tourism

$\mathrm{T}$ he Adriatic is a marginal sea of the Mediterranean. In the past, it used to be described as its largest bay, the Most Important Sea or even the Great Sea. The northern Adriatic as a whole and, particularly, the islands of Cres and Lošinj, are places of many mythological events, which are seen as the main strategic points of maritime trade routes. Because of the amber trade, they are associated with the name of the Electrides, or Amber Islands, while the name of the Apsyrtides refers to the voyage of the Argonauts and the tragic destiny of Apsyrtus, son of King Aeetes of Colchis. The earliest forms of the name of the island have been

I Mithad Kozličić, Historijska geografija istočnog Jadrana u starom vijeku (Split: Književni krug, 1990), 48-52; Martina Blečić Kavur, Povezanostperspective. Osor u kulturnim kontaktima mladeg željeznog doba/A Coherance of perspective. Osor in cultural contacts during the Late Iron Age (Koper: Založba Univerze na Primorskem, 2015), i I. preserved in works by Hellenic and Latin writers (Pseudo-Scylax, Pseudo-Skymnus, Apollonius of Rhodes, Strabo, Pliny) ${ }^{2}$.

Since ancient times, the islands of Cres and Lošinj, with the surrounding islands and reefs, have been an unavoidable element of the navigation route leading through the northern Adriatic. This is partially caused by the indented coastline and numerous protected and sheltered bays, but the main reason is the method of navigation. Through history, navigation boils down to human instinct and the power of perception, respectively to the orientation toward points on the mainland. The main problem of sailors at sea was to determine the position and direction of

2 Marin Zaninović, »Apsorus i Crexa na Jadranskom putu«. Senjski zbornik: prilozi za geografiju, etnologiju, gospodarstvo, povijest $i$ kultu$r u$ 32/I (2005), 5; Zrinka Ettinger Starčić, Underwater archaeological sites of the Losinj Archipelago (Mali Lošinj, 2013), I8. 
movement on the high seas, so they sailed mostly sticking to the coast, from one cape to another. The most important element in the art of navigation was the wind, as the main driving force and direction determiner ${ }^{3}$.

The sea off the islands of Cres and Lošinj and the surrounding islands abounds with diverse archaeological material and is a source of rich and precious cultural heritage. The systematic archaeological reconnaissance has identified more than 20 archaeological sites containing numerous and diverse movable archaeological finds and immovable material such as architectural remains and shipwrecks, datable to the periods ranging from the classical antiquity and the modern era ${ }^{4}$.

Numerous archaeological discoveries have established that the islands of Lošinj and Cres have been important elements in navigation routes throughout history. The discoveries also confirm the continuity of traffic between the Croatian and Italian coasts and the high standard of living in this region.

In 1996, a Belgian tourist, René Wouters, discovered a bronze statue of a young athlete on the seabed in the vicinity of the islet of Vele Orjule near by island of Lošinj. The finding of the statue was reported to the Ministry of Culture of the Republic of Croatia in the autumn of 1998 and it was raised from the sea, in 1999. It was named Apoxyomenos. Most ancient bronzes did not survive Antiquity, since the bronze of the statues was later melted to make dishes, weapons, tools and coins. This statue thus provides us with a rare and precious insight into a little-known art. Apoxyomenos represents a unique finding in the Adriatic, and also in the world. Its integrity and beauty of design distinguish the statue from other finds as a work of art of exceptional quality. It was made in Greece in the $2^{\text {nd }}$ or $\mathrm{I}^{\text {st }}$ century BC. The enthusiasm of the archaeologist and art historians was caused by the fact that the statue has been entirely preserved, with only the little finger of the left hand missing, and part of the

Ettinger Starčić, Underwater archaeological sites, I8.

Ettinger Starčić, Underwater archaeological sites, 20-50. original bronze plinth was still attached to the sole of its right foot.

Immediately after the statue was discovered, its extraordinary cultural and artistic importance incited more general discussion about cultural heritage and the need to preserve it. The beauty and portrayal of details of this unique artistic underwater find have put Croatia and the island of Lošinj on the world heritage map. There are nations much bigger than Croatia, and world-famous museum centres, which cannot boast an artefact as sensational as this one.

In contrast to the situation in Croatia, in many places of the world cultural tourism makes up a very important portion of the activities on offer to the tourist and contributes significantly to the economy. In Croatian tourism as such, and in island tourism in particular, what is offered is still based primarily on sea and sunshine, and only occasionally also includes cultural heritage, which is abundant in Croatia.

In Croatian tourism, especially at the local level, museums are not appreciated at all. During organized tours of towns, tourist guides sometimes just mention that there is a museum here somewhere, but they never take people to visit it, not even when those museums host exceptionally important national or international exhibitions! What is the reason? Despite being locals, tourist workers have no awareness of heritage and its value. But the situation cannot be blamed on tourist workers only. The need to present cultural and archaeological heritage in a more attractive fashion has existed in Croatia for quite some time. Museums are crying out for exhibitions which depart from the usual structure and offer their visitors a multimedia approach. Museum collections present a rare creative and informative potential which will attract visitors if presented in a professional and attractive way, in line with the expectations of today's travellers.

However, we have to be aware that not all cultural products can attract the attention of visitors in the same way; nor do they all have the same value as tourist products. For tourism, the perception of a cultural property as precious is 
sometimes more important than its objective value, and here the marketing can play a key role. Although it is clear that the excellence of a cultural property will probably lead to its positive perception, it is important to estimate whether the presentation of the cultural property is perceived as a special event, an unforgettable or pleasant experience.

The promotion of cultural values should primarily target the local population, which should become fully aware of the richness of their cultural heritage. Cultural heritage and a museum, as its main promoter, play a very important role in the development of a local community's specific identity, and without it, one destination can hardly be distinguished from other similar localities. On the island of Lošinj, the most important part of the local cultural heritage is underwater archaeological finds and sites, used to create specific experiences and to attract visitors and place this destination on the market. An unforgettable experience or a special moment are key factors for the perception of the museum, and some of the main reasons for the selection of this destination.

Until the Museum of Apoxyomenos was opened, neither the local nor the regional tourist industry counted on museums as one of the main baits that could attract contemporary tourists. The reason for this lay in the fact that museums could not or did not know how to place their cultural products on the tourist market, or they lacked the support of the local tourist boards to achieve it. Properties and artefacts that form our cultural heritage can be seen as cultural products which should be wrapped nicely and offered on the market. In the case of museums, the product should be wrapped nicely in a story. Thus the key question for any museum is how to tell the story.

The Museum of Apoxyomenos has succeeded in doing it. The fact that this is a specific museum, dedicated to a sole exhibit, has greatly impacted the development and design of its permanent exhibition. With their inspired vision of the building and its interior, architects Turato and Randić have presented this globally sen- sational archaeological find in an extraordinary way.

They have designed a solution to present a perfect sculpture, set outside any chronological or physical context, while at the same time providing an exciting and comprehensible museum exhibition capable of presenting the statue and its story to the general public.

The Museum of Apoxyomenos and its exhibition represent the spatial materialisation of the ceremony of passing through various rooms and halls on the way to the sculpture. The architecturally shaped body of the new Museum has been inserted in a space defined by the exterior walls and the roof of the existing Kvarner Palace. The museum is built inside the shell of an old building, with the architects incorporating a completely new design within it, "a house within a house". The structure is formed inside a steel structure.

The exhibition display is defined by the idea of passing through the building by visiting nine scenes and transition zones shaped by time and space, and accompanied by the corresponding audio background. Visitors enter the museum via the multi-functional atrium, known as the "blue room". The striking room is coloured deep blue, transforming the inner walls of the palace.

From there an escalator takes groups of up to 20 through a white-painted tube, leading them to the main exhibition hall - the "black room". In this cold, dark area, visitors can experience what it feels like being $45 \mathrm{~m}$ under the sea, and they can learn about the history, context, discovery, and restoration of Apoxyomenos from illuminated displays detailing the statue's past.

Visitors then move on to the "colourful room" - an amphitheatre clad in merino-wool carpet designed by Studio KulenTurato, with its bright and contrasting design intended to create the feeling of walking over a seabed, symbolising the unique story of how the statue was recovered and its visual history. The "red passage" is next, in the form of a narrow staircase leading to the "yellow room" - a media-inspired room 
by MKF\&AT and Bosnic+Dorotic - looking at the media coverage relating to the statue.

In the build-up to the grand unveiling, the "olive passage" is a staircase made of olivewood, with inset chambers containing natural elements such as wood and leaves originally found inside the sculpture. The scent of oil and olives is also pumped into the room as visitors get a first glimpse at Apoxyomenos.

By visiting and experiencing those various, dynamic and impressive rooms, and by getting acquainted with their content, visitors are getting ready for the final scene: the "White Room", a completely white and silent room whose walls are covered in textile, and whose only tenant is the bronze Apoxyomenos. After meeting the sculpture, the visitors get to experience one final emotion by visiting the "Kaleidoscope Room", a lookout at the top of the Museum situated in a space in which various sequences from the Lošinj harbour are reflected in the mirrors on the ceiling. (Fig.9. Kaleidoscope room, photo Bosnic\&Dorotic)

This museum activates all the senses.

The opening of the Museum of Apoxyomenos in Mali Lošinj - the first museum on the Adriatic fully dedicated to underwater archaeology - indirectly presents the northern Adriatic (the Kvarner Bay) as an area of high classical civilization. In this museum exhibition, one exhibit, presented in an entirely modern concept of artistic projection and promotion, changes the perception of the cultural-heritage space, extending it from the coast to under the sea.

The ever-growing public interest in underwater cultural heritage has changed the perception of underwater archaeology, and even the local community has begun to see it as a scientific discipline which is not an end in itself, but serves and benefits the community. Thus underwater archaeology, and underwater archaeological heritage, have become an exceptionally valuable 'home-made product', a resource for cultural tourism and the local economy.

In such a social environment, from being a tourist attraction and the most important el- ement on offer to the tourist, Apoxyomenos is gradually becoming a brand and a basis for cultural tourism, and as such it makes an essential contribution to the economy of the region.

The presentation of Apoxyomenos is now entering its next phase in which it will grow out of its geographical boundaries and become an integral part of wider promotional and presentation networks. An obvious course of action would be to establish one or more routes along the eastern Adriatic coast, which would be used to present the underwater heritage - and also the land heritage connected to it - of the Roman Empire, or of the whole the classical antiquity (which would then also include Greek colonies). The next step would be setting up an Adriatic network which would also include archaeological sites on the Italian coast, and in Montenegro and Albania, and possibly also in Greece. The third most important step would be the inclusion of the Croatian coast in similar Mediterranean routes which are already operational or are being developed. This refers particularly to the routes established within the European Commission's projects, since it would facilitate their future funding by the European funds. One such route includes the most important underwater-archaeology sites in the Mediterranean. With its contents, the Museum of Apoxyomenos satisfies all the criteria for inclusion in the most prestigious presentation networks, which would enable it to become a driving force of development, quality-raising and inclusion of further Croatian destinations into such and similar networks.

\section{Povzetek}

Nedavno odprti Apoksiomenov Muzej v Malem Lošinju - prvi muzej na Jadranu, ki je v celoti posvečen podvodni arheologiji - naravnost predstavlja severni Jadran (Kvarnerski zaliv) kot prostor visoke civilizacije v antiki. $\mathrm{V}$ tej muzejski postavitvi en razstavljeni predmet, predstavljen na povsem moderen način umetniške projekcije in promocije, spreminja dojemanje kulturno dediščinskega prostora, ki ga širi od obale do podvodnega sveta. Rastoči javni interes za podvodno kulturno dedišči- 
no je spremenil dojemanje podvodne arheologije, da jo je celo lokalna skupnost začela prepoznavati kot znanstveno disciplino, ki ni namenjena sama sebi, pač pa služi interesom skupnosti. V takšnem družbenem okolju Apoxyomenos, ki se je iz turistične atrakcije prelevil v enega najpomembnejših členov turistične ponudbe, postopoma postaja tržna znamka in temelj kulturnega turizma, kot tak pa bistveno prispeva h gospodarski sliki regije.

\section{Summary}

The opening of the Apoxyomenos Museum in Mali Lošinj-the first museum on the Adriatic fully dedicated to underwater archaeology-indirectly presents the northern Adriatic (the Kvarner Bay) as an area of high classical civilisation. In this museum exhibition, one exhibit, presented in an entirely modern concept of artistic projection and promotion, changes the perception of the cultural-heritage space, extending it from the coast to under the sea. The ever-growing public interest in underwater cultural heritage has changed the perception of underwater archaeology, and even the local community has begun seeing it as a scientific discipline, which is not an end in itself, but serves and benefits the community. In this societal environment, from being a tourist attraction and the most important of elements on offer to the tourist, Apoxyomenos is gradually becoming a brand and basis of cultural tourism, and as such makes an essential contribution to the economy of the region.

\section{Bibliography}

Blečić Kavur, Martina. Povezanost perspective. Osor u kulturnim kontaktima mladeg željeznog dobal A Coherance of perspective. Osor in cultural contacts during the Late Iron Age. Koper: Založba Univerze na Primorskem, 2015.

Ettinger Starčić, Zrinka. Underwater archaeological sites of the Losinj Archipelago, Mali Lošinj, 2013.

Kozličić, Mithad. Historijska geografija istočnog Jadrana u starom vijeku, Split: Književni krug, 1990.

Radić Rossi, Irena. »Plovidba Jadranom u grčko doba«. In: J. Poklečki Stošić (ed),
Antički Grci na tlu Hrvatske, 9I-IOI. Zagreb: Galerija Klovićevi dvori, 2010. Zaninović, Marin. »Apsorus i Crexa na Jadranskom putu«. Senjski zbornik: prilozi za geografiju, etnologiju, gospodarstvo, povijest $i$ kulturu, 32/I (2005), 5-24. 